\title{
Alterations of Stress Parameters and Histology of Asian Catfish (Pangasius hypophthalmus) in Transport
}

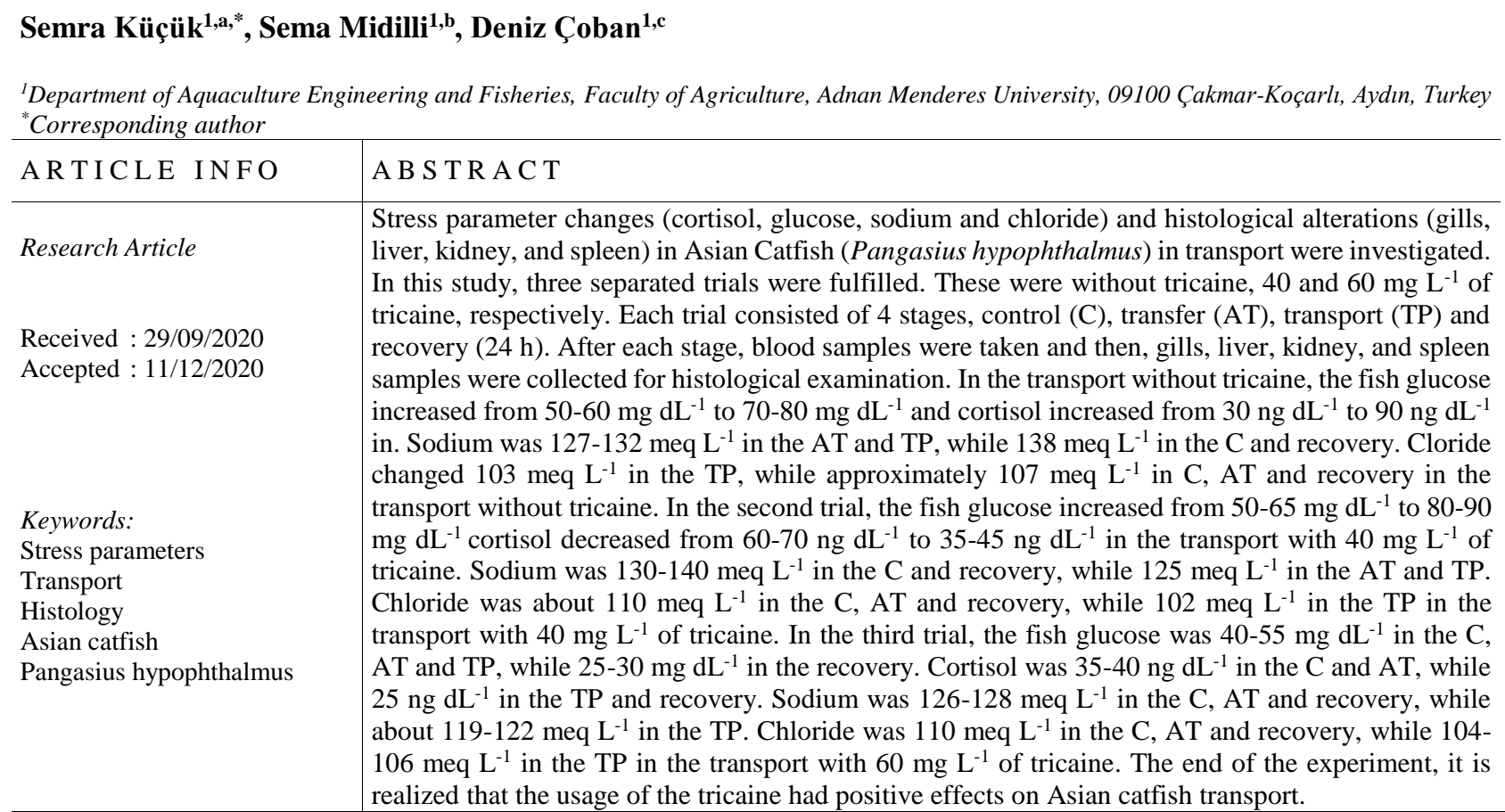

Türk Tarım - Gıda Bilim ve Teknoloji Dergisi, 9(2): 326-332, 2021

\section{Transport Aşamasında Asya Kedi Balıklarının (Pangasius hypophthalmus) Histolojilerinde ve Stres Parametrelerindeki Değişimiler}

\begin{tabular}{|c|c|}
\hline M A K A L E B İ L G İ S İ & $\ddot{0} \mathrm{Z}$ \\
\hline $\begin{array}{l}\text { Anahtar Kelimeler: } \\
\text { Stres parametreleri } \\
\text { Transport } \\
\text { Histoloji } \\
\text { Asya kedi balığ } 1 \\
\text { Pangasius hypophthalmus }\end{array}$ & 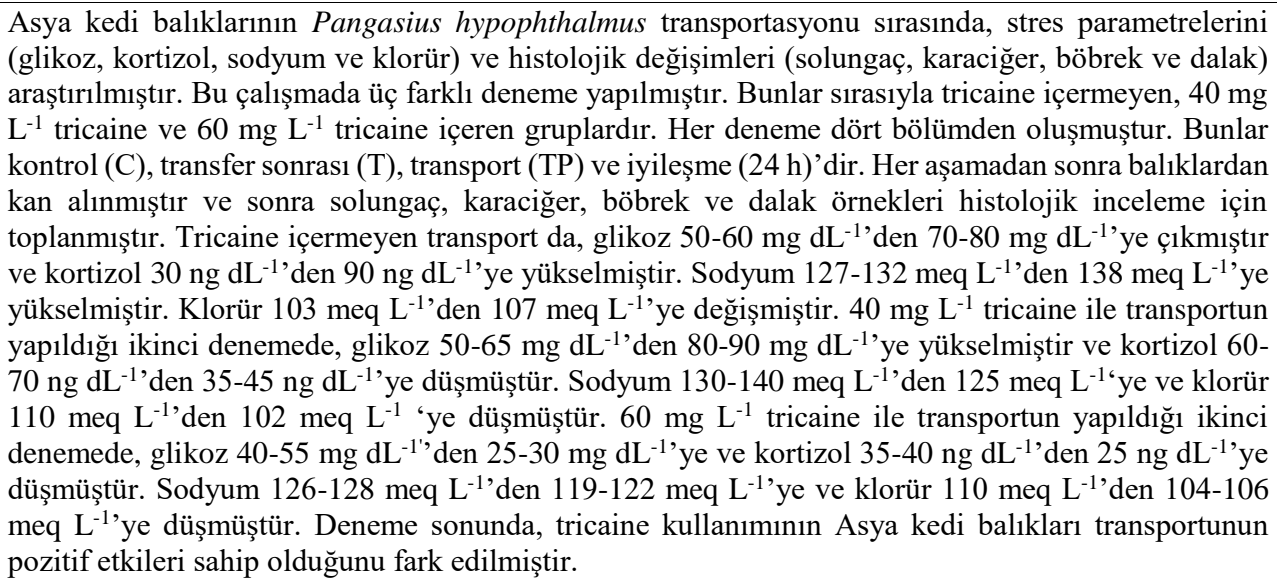 \\
\hline
\end{tabular}




\section{Introduction}

As known during fish culture there are many factors causing acute and chronic stress on fish such as culturing in ponds, handling, measuring length and weight, stocking, transport etc. Transport is an important stress procedure that caused many physiological changes to fish. Especially fish exposed to mechanic eration in their skin because of high intensity and touching each other.

Modern aquaculture practices exposed fish to many kind of stress factors that negatively affect fish performance and survival. Fish are exposed to many stress (intensity, handling, water quality, water move, noise, vibration, transport). These kind of stress may cause many important physiological alternation in fish. There are some studies mentioned that bad condition factors negatively affect animal health and cause stress (Warris, 1998; Broom, 2005). Control of water quality and fish sedation during transport can be useful tools to minimize stress (Ross \& Ross, 2008). Tricaine (MS-222), benzocaine hydrochloride, 2-phenoxyethanol and lidocaine hydrochloride have been used an anaesthetic to reduce stress responses during live fish transportation (Carmichael et al. 1984; Ferreira et al. 1984; Teo et al. 1989; Singh et al. 2004; Park et al. 2009). Some studies have been done about the fish transport with anaesthetic usage to alleviate the stress on some fish species such as Atlantic salmon (Salmo salar) (Iversen et al., 1998), rainbow trout (Oncorhynchus mykiss) (Chandron et al., 2005; Kubilay and Uluköy, 2002), African catfish (Clarias gariepinius) (Manuel et al., 2014), carp (Cyprinus carpio) (Mazandarani et al., 2017; Svobodova et al., 1999) in cobia (Rachycentron canadum) (Pedron et al., 2016), European perch (Perca fluviatilis) (Accerete et al., 2004).

The aim of this study is to dedicate the changes about the transport causing stress parameters (glucose, cortisol, $\mathrm{Na}+, \mathrm{Cl}-$, hematocrit, $\mathrm{RBC}$, hemoglobin) and histological analysis of the Asian catfish (Pangasius hyphthalmus).

\section{Material and Methods}

\section{Experimental Fish}

This experiment was carried out in the wet laboratory. Commercially obtained fish were reared from the fingerling size to conduct this experiment. Fish stock was about 594. Prior to the experiment, fish were held in 3 maintenance aquarium $(100 \times 30 \times 45 \mathrm{~cm})$ for one week. Fish were starved for $24 \mathrm{~h}$ before experiment started. Each aquarium was continuously supplied with each outer filter system. Water quality parameters (temperature, $\mathrm{pH}$, dissoled oxygen) were measured once a day with the multiparameter (WTW Multi 3420 set G). Air temperature was holded constant $\left(24^{\circ} \mathrm{C}\right)$ in the laboratory by the AC. Fish were fed during the all trials. Before transport, additional aeration was supplied to all bags used in transport. Mortality was recorded during the all trials.

\section{Fish Loading and Transport Procedure}

This experiment was conducted in three different trials and each trial consisted of 4 stages, control (C), transfer (AT), transport (TP) and recovery (24 h). First trial was the transport fish in the water without tricaine (MS-222). Second trial was the transport fish in the water with $40 \mathrm{mg}$ L-1 of tricaine and third trial was the transport fish in the water with $60 \mathrm{mg} \mathrm{L}-1$ of tricaine.
In the first trial, fish were speedily captured from maintenance aquarium in order to measure stress parameters during the handling procedure. Nine fish $(15.60 \pm 8.46 \mathrm{~mm}, 34.27 \pm 1.59 \mathrm{~g})$ were randomly sampled for blood and histological analysis. These data were used as a control (C) in my study. Fish were stocked to the polyethelene bags $(30 \times 90 \mathrm{~cm})$ held about $12 \mathrm{~L}$ of the water without tricaine. This part was used as a transfer stage (AT), one fish from each bag $(13.23 \pm 0.61 \mathrm{~mm}, 19.73 \pm 2.79$ g) were randomly sampled. Then, each bag was supported with oxygen and then it was tied up until the fish were transported for $4 \mathrm{~h}$. This part was used as a transport stage (TP). After that, one fish from each bag $(14.6 \pm 0.3 \mathrm{~mm}$, $24.3 \pm 0.8 \mathrm{~g}$ ) were randomly sampled. At the end this trial, fish were waited for $24 \mathrm{~h}$ for the recovery. This part was used as a recovery $(24 \mathrm{~h})$. After this, one fish from each bag $(14.8 \pm 1.4 \mathrm{~mm}, 24.8 \pm 5.9 \mathrm{~g})$ were sampled for blood and histological analysis.

In the second trial, fish were passed through the same procedure like in the first trial. Nine fish $(25.1 \pm 3.5 \mathrm{~mm}$, $14.0 \pm 0.7 \mathrm{~g}$ ) were used in the control stage (C) for blood and histological analysis. After that, fish were stocked to polyethelene bags with $12 \mathrm{~L}$ of the water with $40 \mathrm{mg} \mathrm{L}-1$ of the tricaine at three densities $(16,21,26)$. Each density had three repeats. One fish from each bag $(12.8 \pm 0.2 \mathrm{~mm}$, $20.8 \pm 2.3 \mathrm{~g}$ ) were randomly sampled in the transfer stage (AT) for blood and histological analysis. And then, each bag was supporting with oxygen and tied up until the fish transported (TP) for $4 \mathrm{~h}$. After that, one fish from each bag $(14.6 \pm 1.0 \mathrm{~mm}, 25.7 \pm 5.6 \mathrm{~g})$ were randomly sampled for blood and histological analysis. Finally, fish were waited for $24 \mathrm{~h}$ for the recovery. One fish from each bag (15.2 \pm 1.0 $\mathrm{mm}, 28.8 \pm 4.3 \mathrm{~g}$ ) were sampled for blood and histological analysis.

In the third trial, fish were immediately taken from maintenance aquarium and totaly nine fish $(15.3 \pm 0.7 \mathrm{~mm}$, $30.2 \pm 4.2 \mathrm{~g}$ ) were randomly sampled for blood and histological analysis as a control (C). After that, fish were stocked to polyethelene bags $(30 \times 90 \mathrm{~cm})$ with $12 \mathrm{~L}$ of the water with $60 \mathrm{mg} \mathrm{L}-1$ of the tricaine at three densities (16, $21,26)$. Each density had three repeats. After transfer stage (AT), one fish from each bag $(13.6 \pm 1.1 \mathrm{~mm}, 22.3 \pm 5.0 \mathrm{~g})$ were randomly sampled for blood and histological analysis. And then, each bag was supporting with oxygen and tied up until the fish were transported (TP) for $4 \mathrm{~h}$. Transport continued for $4 \mathrm{~h}$. One fish from each bag (16.4 $\pm 1.1 \mathrm{~mm}, 34.7 \pm 6.4 \mathrm{~g}$ ) were randomly sampled for blood and histological analysis. Finally, fish were waited for recovery for $24 \mathrm{~h}$. One fish from each bag $(16.4 \pm 1.0 \mathrm{~mm}$, $33.5 \pm 6.4 \mathrm{~g}$ ) were sampled for blood and histological analysis.

\section{Blood Analysis}

Fish blood was taken by puncture of the caudal vessels with the vacutainer tubes (containing EDTA) and needles under cool chain. Blood samples were analysed in the private laboratory for stress parameters (cortisol, glucose, $\mathrm{Na}+, \mathrm{Cl}-, \mathrm{RBC}$, hemoglobin, hematocrit). 


\section{Histological Analysis}

Gill, liver, kidney, and spleen tissue samples were collected from the selected fish and fixed in the $10 \%$ of formalin for at least $24 \mathrm{~h}$. Then, tissue samples were dehydrated in graded ethanol concentrations (Roberts, 2012), embedded in paraffin wax. Then the rotary microtome machine (Leica RM 2125 RTS) was used for cutting about the $5 \mu$ slices from the emmbedded tissue blocks in a paraffin. After that, those sections mounted on glass slides and deparaffinized in xylen solution. And then, the samples on the glass slides were stained with the hematoxylin and eosin solution (Culling et al., 1985). After that, the histological slides were examined with the light microscope (Euromex Novex B series). And then the symptoms were determined and the images were taken by the micro-camera (Novex Cmex DC 5000).

\section{Statistical Analysis}

Differences in the trials and stages were tested by the analysis of the variance (ANOVA). Homogen variances were compared with the Tukey $(\mathrm{P}<0.05)$. Results were given as means \pm standart deviation (SD).

\section{Results and Discussion}

The First Trial of the Transport in the Water Without Tricaine

Fish blood parameters were given in the Table 1 . Glucose was $50-60 \mathrm{mg} \mathrm{dL}-1$ in the $\mathrm{C}$ stage, while $70-80 \mathrm{mg}$ $\mathrm{dL}-1$ in the AT and TP and decreased to stable level $(40 \mathrm{mg}$ $\mathrm{dL}-1$ ) in the recovery (Figure 1). Cortisol was $30 \mathrm{ng} \mathrm{dL}-1$ in the $\mathrm{C}$ and AT, while $90 \mathrm{ng} \mathrm{dL}-1$ in the TP and decreased to $20 \mathrm{ng} \mathrm{dL}-1$ in the recovery (Figure 2). Sodium was 127-132 meq L-1 in the AT and TP, while 138 meq L- 1 in the C and recovery. Cloride was $103 \mathrm{meq} \mathrm{L}-1$ in the TP, while approximately $107 \mathrm{meq} \mathrm{L-1}$ in C, AT and recovery. Hematocrit and RBC did not change, but some changes were present in the hemoglobin.

Iversen et al. (1998) studied about stress occurred after loading and transport of smolt of Atlantic salmon (Salmo salar). Fish was transported to Bondhus river for $4.5 \mathrm{~h}$, to Surna river for $2.5 \mathrm{~h}$ and to Eira river for $0.5 \mathrm{~h}$. After transport $0,0.5,1,24$ and $48 \mathrm{~h}$, fish were bled and measured stress parameters. While cortisol was zero in control group, it was $450 \mathrm{mmol} / \mathrm{L}$ after $0.5 \mathrm{~h} 500 \mathrm{mmol} / \mathrm{L}$ after $1 \mathrm{~h}$. Glucose was $7.5 \mathrm{mmol} / \mathrm{L}$ after $0.5 \mathrm{~h}, 8.5 \mathrm{mmol} \mathrm{L}-1$ after $1 \mathrm{~h}$. Sodium was 30-165 mmol L-1 in control group and it was 176-211 mmol L-1for $24 \mathrm{~h}$. Chloride was 133-138 mmol L-1 in control group and it was 151-181 mmol L-1 for 24 .
Kubilay and Uluköy (2002) exposed rainbow trout (Oncorhychus mykiss) to acute stress (transport, handling and stocking in a small area). They measured cortisol, glucose and lysozyme activities. Depending on stress, cortisol increased from $31.50 \mu \mathrm{g} \mathrm{dL}-1$ to $45.16 \mu \mathrm{g} \mathrm{dL}-1$. At the same way, glucose increased from 26.23 to $58.53 \mathrm{mg} \mathrm{dL}-1$.

Acerete et al. (2004) exposed the European perch (Perca fluviatilis) to stress of transport and handling. After transport $0,2,7,14,21$ days, cortisol increased $140 \mathrm{ng} \mathrm{ml-}$ 1 after 2 days, although control was $40 \mathrm{ng} \mathrm{ml}-1$. Glucose was maximum $70 \mathrm{mg} \mathrm{dL}-1$ after 2 days, although it was 50 mg dL-1. Additionally, after 0, 0.5, 1, 4 and $24 \mathrm{~h}$, they measured fish stress parameters. Cortisol was $120 \mathrm{ng} \mathrm{ml}-1$ for $0.5 \mathrm{~h}$, even though control was $40 \mathrm{ng} \mathrm{ml-1}$. Glucose was $60 \mathrm{mg} \mathrm{dL}-1$ for $1 \mathrm{~h}$, even though $40 \mathrm{mg} \mathrm{dL}-1$.

Urbinati et al. (2004) exposed Brycon cephalus to stress. Fish was in three different intensities (83, 125, 166 g L-1) after five stages (before loading, after transfer, after transport, after 24-h recovery and 96-h recovery) fish glucose, cortisol, chloride, osmolalite, hematocrit and number of erythrocyte were measured in blood. They showed glucose and cortisol increased after transport, chloride and hematocrit decreased and number of erythrocyte did not affect.

Jentoft et al. (2005) exposed European wild perch (P. fluviatilis) and cultured rainbow trout (O. mykiss) to stress. Fish growth, cortisol, and glucose were measured. After 8 weeks, perch grew from $10 \mathrm{~g}$ to $40 \mathrm{~g}$ under non stress condition. They reached $25 \mathrm{~g}$ under continuous stress condition. Trout grew from $20 \mathrm{~g}$ to $120 \mathrm{~g}$ under non stress condition. They were reared $90 \mathrm{~g}$ under continuous stress condition. In these two fish species, cortisol and glucose were measured after $0,0.5,1,3,6$ and $24 \mathrm{~h}$. Cortisol was $200 \mathrm{ng} \mathrm{ml}-1$ after $0.5 \mathrm{~h}$ in European perch under one stress condition. It was $120 \mathrm{ng} \mathrm{ml}-1$ after $0.5 \mathrm{~h}$, it decreased 50 ng ml-1 after $3 \mathrm{~h}$ under continuous stress condition. Cortisol in trout was $175 \mathrm{ng} \mathrm{ml}-1$ after $1 \mathrm{~h}$ and decreased $40 \mathrm{ng} \mathrm{ml}-1$ after $3 \mathrm{~h}$ under one stress condition. It was 150 ng ml-1 after $0.5 \mathrm{~h}$ and $40 \mathrm{ng} \mathrm{ml}-1$ after $3 \mathrm{~h}$ under continuous stress condition. Glucose was the same in two stress group (20 mM after $1 \mathrm{~h}$ ) after $3 \mathrm{~h}$ in one stress group it was $7 \mathrm{mM}$. In the continuous stress group, it was $6 \mathrm{mM}$. After $24 \mathrm{~h}$ two stress group decreased $5 \mathrm{mM}$. Gomes (2007) exposed pirarucu (Arapaima gigas) to transport and handling stress. After 0, 6, 24, 48 and $96 \mathrm{~h}$. Six fish were bled and measured lactose, glucose, cortisol, hematocrit, hemoglobin, liver glycogen. After stress glucose, cortisol and hematocrit increased and hemoglobin also changed.

Table 1. Stress parameters (glucose, cortisol, sodium, chloride, RBC, HGB, HCT) in the trial of transport without tricaine

\begin{tabular}{l|cccccccc}
\hline Stages & Intensity & Glucose & Cortisol & Sodium & Chloride & RBC & HGB & HCT \\
\hline \multirow{3}{*}{ C } & 16 & $59.2 \pm 8.2$ & $25.7 \pm 2.7$ & $136.7 \pm 11.2$ & $106.6 \pm 4.8$ & $2.2 \pm 0.8$ & $12.8 \pm 0.4$ & $29.0 \pm 9.7$ \\
& 21 & $56.5 \pm 6.4$ & $32.7 \pm 15$ & $139.3 \pm 9.1$ & $106.4 \pm 4.9$ & $2.4 \pm 0.5$ & $11.9 \pm 1.9$ & $32.3 \pm 6.5$ \\
& 26 & $48.4 \pm 5.5$ & $22.5 \pm 4.1$ & $135.7 \pm 12.7$ & $107.2 \pm 3.9$ & $2.2 \pm 0.5$ & $10.5 \pm 2.1$ & $29.0 \pm 7.1$ \\
\hline \multirow{3}{*}{ AT } & 16 & $76.2 \pm 9.1$ & $26.4 \pm 7.8$ & $130.7 \pm 1.2$ & $106.5 \pm 5.9$ & $2.8 \pm 0.1$ & $13.8 \pm 0.2$ & $36.1 \pm 1.0$ \\
& 21 & $78.2 \pm 3.0$ & $30.9 \pm 10.7$ & $128.7 \pm 6.1$ & $106.9 \pm 1.0$ & $2.9 \pm 0.6$ & $14.2 \pm 2.2$ & $37.4 \pm 6.4$ \\
& 26 & $77.0 \pm 17.8$ & $27.9 \pm 2.0$ & $127.7 \pm 9.6$ & $107.5 \pm 14.2$ & $2.8 \pm 0.4$ & $13.1 \pm 1.7$ & $35.4 \pm 5.0$ \\
\hline \multirow{3}{*}{ TP } & 16 & $68.1 \pm 5.8$ & $90.0 \pm 8.3$ & $129.3 \pm 1.2$ & $103.5 \pm 4.0$ & $2.6 \pm 0.1$ & $12.7 \pm 0.5$ & $31.7 \pm 1.2$ \\
& 21 & $67.4 \pm 9.4$ & $86.4 \pm 17.7$ & $131.7 \pm 6.4$ & $104.1 \pm 2.6$ & $2.8 \pm 0.1$ & $11.5 \pm 0.9$ & $30.1 \pm 3.3$ \\
& 26 & $66.3 \pm 1.2$ & $87.0 \pm 8.5$ & $132.3 \pm 10.5$ & $103.7 \pm 3.5$ & $2.5 \pm 0.6$ & $11.8 \pm 2.5$ & $28.9 \pm 4.5$ \\
\hline \multirow{3}{*}{$24 \mathrm{~h}$} & 16 & $41.8 \pm 1.5$ & $22.4 \pm 3.4$ & $136.3 \pm 1.5$ & $107.0 \pm 3.9$ & $2.6 \pm 0.1$ & $13.2 \pm 0.3$ & $32.9 \pm 1.4$ \\
& 21 & $38.7 \pm 1.4$ & $21.3 \pm 2.3$ & $139.0 \pm 10.8$ & $106.8 \pm 3.4$ & $2.8 \pm 0.1$ & $13.0 \pm 0.3$ & $33.8 \pm 0.7$ \\
& 26 & $40.2 \pm 2.0$ & $25.1 \pm 4.7$ & $138.3 \pm 6.8$ & $106.9 \pm 3.2$ & $2.9 \pm 0.2$ & $14.1 \pm 0.1$ & $36.5 \pm 1.5$ \\
\hline
\end{tabular}

*RBC: Red blood cells, HGB: Hemoglobin, HCT: Hemotocrit 
Table 2. Stress parameters (glucose, cortisol, sodium, chloride, RBC, HGB, HCT) in the trial of transport with $40 \mathrm{mg} \mathrm{L}^{-1}$ tricaine

\begin{tabular}{l|cccccccc}
\hline Stages & Intensity & Glucose & Cortisol & Sodium & Chloride & RBC & HGB & HCT \\
\hline \multirow{3}{*}{$\mathrm{Cl}$} & 16 & $70.2 \pm 10.3$ & $57.4 \pm 15.3$ & $137.4 \pm 8.8$ & $109.0 \pm 5.8$ & $2.2 \pm 0.2$ & $11.7 \pm 0.9$ & $29.0 \pm 2.8$ \\
& 21 & $48.9 \pm 10.7$ & $60.9 \pm 15.6$ & $139.0 \pm 1.0$ & $108.1 \pm 7.1$ & $2.1 \pm 0.2$ & $7.9 \pm 4.1$ & $27.5 \pm 1.3$ \\
& 26 & $58.4 \pm 16.5$ & $70.6 \pm 6.8$ & $138.4 \pm 7.5$ & $107.4 \pm 9.4$ & $2.3 \pm 0.3$ & $11.8 \pm 0.9$ & $29.4 \pm 3.1$ \\
\hline \multirow{3}{*}{$\mathrm{AT}$} & 16 & $83.4 \pm 8.7$ & $64.0 \pm 49.1$ & $133.0 \pm 12.6$ & $107.7 \pm 1.4$ & $2.0 \pm 0.2$ & $10.3 \pm 1.0$ & $25.0 \pm 2.1$ \\
& 21 & $93.5 \pm 8.2$ & $63.9 \pm 20.5$ & $129.9 \pm 5.8$ & $108.8 \pm 6.3$ & $2.0 \pm 0.1$ & $11.0 \pm 0.5$ & $26.6 \pm 1.6$ \\
& 26 & $88.9 \pm 11.7$ & $64.1 \pm 32.2$ & $131.1 \pm 6.7$ & $110.0 \pm 3.0$ & $2.1 \pm 0.2$ & $11.4 \pm 0.7$ & $27.5 \pm 3.4$ \\
\hline \multirow{3}{*}{$\mathrm{TP}$} & 16 & $49.3 \pm 7.3$ & $44.2 \pm 7.5$ & $123.3 \pm 2.9$ & $101.8 \pm 4.1$ & $2.1 \pm 0.2$ & $10.4 \pm 1.2$ & $24.8 \pm 3.1$ \\
& 21 & $66.2 \pm 8.7$ & $45.4 \pm 4.1$ & $128.3 \pm 2.9$ & $101.7 \pm 0.6$ & $2.2 \pm 0.3$ & $12.3 \pm 1.7$ & $25.0 \pm 1.0$ \\
& 26 & $54.7 \pm 10.6$ & $36.1 \pm 5.5$ & $127.9 \pm 5.9$ & $101.7 \pm 5.7$ & $2.2 \pm 0.2$ & $11.6 \pm 0.8$ & $25.5 \pm 1.5$ \\
\hline \multirow{3}{*}{$24 \mathrm{~h}$} & 16 & $66.6 \pm 9.2$ & $45.8 \pm 11.3$ & $137.1 \pm 8.7$ & $111.2 \pm 2.6$ & $2.6 \pm 0.4$ & $13.2 \pm 1.1$ & $31.6 \pm 4.5$ \\
& 21 & $64.6 \pm 6.4$ & $46.5 \pm 3.8$ & $134.0 \pm 6.6$ & $110.0 \pm 7.2$ & $2.6 \pm 0.3$ & $13.5 \pm 0.9$ & $32.1 \pm 2.9$ \\
& 26 & $67.2 \pm 18.4$ & $41.2 \pm 7.0$ & $139.1 \pm 2.8$ & $106.7 \pm 4.2$ & $2.3 \pm 0.1$ & $12.9 \pm 0.7$ & $30.3 \pm 1.4$ \\
\hline
\end{tabular}

*RBC: Red blood cells, HGB: Hemoglobin, HCT: Hemotocrit

Table 3. Stress parameters (glucose, cortisol, sodium, chloride, RBC, HGB, HCT) in the trial of transport with $60 \mathrm{mg} \mathrm{L}^{-1}$ of tricaine

\begin{tabular}{l|cccccccc}
\hline Stages & Intensity & Glucose & Cortisol & Sodium & Chloride & RBC & HGB & HCT \\
\hline \multirow{3}{*}{ C } & 16 & $42.5 \pm 3.2$ & $36.4 \pm 10.0$ & $126.1 \pm 1.7$ & $109.0 \pm 3.6$ & $2.5 \pm 0.2$ & $12.7 \pm 0.4$ & $36.0 \pm 2.8$ \\
& 21 & $53.5 \pm 3.4$ & $35.8 \pm 4.5$ & $126.7 \pm 2.3$ & $110.0 \pm 5.0$ & $2.6 \pm 0.1$ & $12.4 \pm 0.8$ & $36.2 \pm 0.9$ \\
& 26 & $47.6 \pm 3.0$ & $37.6 \pm 11.2$ & $126.7 \pm 2.3$ & $109.7 \pm 2.5$ & $2.7 \pm 0.1$ & $13.6 \pm 0.1$ & $40.4 \pm 0.7$ \\
\hline \multirow{3}{*}{ AT } & 16 & $47.4 \pm 0.3$ & $36.9 \pm 1.1$ & $125.9 \pm 2.3$ & $109.7 \pm 2.5$ & $2.4 \pm 0.0$ & $12.1 \pm 0.3$ & $34.1 \pm 1.9$ \\
& 21 & $52.8 \pm 1.3$ & $38.5 \pm 5.8$ & $122.9 \pm 5.5$ & $109.6 \pm 2.7$ & $2.3 \pm 0.2$ & $11.9 \pm 0.6$ & $32.7 \pm 2.1$ \\
& 26 & $42.7 \pm 9.1$ & $42.5 \pm 2.2$ & $128.3 \pm 3.9$ & $109.7 \pm 3.9$ & $2.5 \pm 0.1$ & $12.3 \pm 1.0$ & $34.2 \pm 3.6$ \\
\hline \multirow{3}{*}{ TP } & 16 & $40.7 \pm 5.2$ & $25.8 \pm 3.0$ & $120.8 \pm 3.9$ & $104.4 \pm 3.1$ & $2.1 \pm 0.6$ & $11.1 \pm 3.2$ & $31.3 \pm 9.3$ \\
& 21 & $40.0 \pm 3.3$ & $25.7 \pm 2.5$ & $123.1 \pm 8.8$ & $106.0 \pm 4.0$ & $2.1 \pm 0.3$ & $10.0 \pm 1.4$ & $28.0 \pm 3.8$ \\
& 26 & $41.8 \pm 1.1$ & $26.7 \pm 5.4$ & $119.3 \pm 3.7$ & $103.0 \pm 3.2$ & $2.6 \pm 0.1$ & $12.5 \pm 1.2$ & $31.2 \pm 4.0$ \\
\hline \multirow{3}{*}{$24 \mathrm{~h}$} & 16 & $25.0 \pm 11.4$ & $27.7 \pm 1.9$ & $124.7 \pm 3.1$ & $109.0 \pm 3.6$ & $2.4 \pm 0.2$ & $12.5 \pm 0.3$ & $31.6 \pm 1.6$ \\
& 21 & $30.0 \pm 9.3$ & $28.6 \pm 6.3$ & $124.1 \pm 10.8$ & $108.3 \pm 1.5$ & $2.3 \pm 0.2$ & $11.6 \pm 1.3$ & $30.5 \pm 6.1$ \\
& 26 & $26.5 \pm 13.4$ & $27.9 \pm 8.0$ & $126.8 \pm 6.6$ & $109.0 \pm 1.0$ & $2.6 \pm 0.5$ & $12.7 \pm 1.7$ & $31.8 \pm 1.6$ \\
\hline
\end{tabular}

*RBC: Red blood cells, HGB: Hemoglobin, HCT: Hemotocrit

\section{The Second Trial of the Transport in the $60 \mathrm{mg} \mathrm{L-1} \mathrm{of}$ Tricaine Solution}

Glucose was 50-65 mg/dL in the C, TP and $24 \mathrm{~h}$, while 80-90 mg dL-1 in the AT (Table 2, Figure 3). Cortisol was 60$70 \mathrm{ng} \mathrm{dL}-1$ in the $\mathrm{C}$ and AT, while approximately $35-45 \mathrm{ng}$ $\mathrm{dL}-1$ in the TP and recovery (Figure 4). Sodium was 130-140 meq L-1 in the C and recovery, while 125 meq L-1 in the AT and TP. Chloride was about 110 meq L-1 in the C, AT and recovery, while 102 meq L-1 in the TP. Hematocrit and RBC did not show any important changes in the all stages. Glucose increased after transport, but cortisol was $60 \mathrm{ng} \mathrm{dL}-1$ in the $\mathrm{C}$ and AT. And then decreased 35-45 ng dL-1 in the recovery. Additionally, the ion balance was not changed much in the second trial. There are some studies which are the similar to my study results.

Svobodova et al. (1999) exposed carp (Cyprinus carpio) to menocaine and they only said that glucose decreased and cortisol did not change. Park et al., (2009) used lindocaine-hydrochloride for transport of juvenile flounder (Pleuronectes americanus). They found that lindocaine is effective anaesthetic. Becker et al., (2017) used Aloysia triphylla as an anesthetics. They reported that this essential oil could be applicated to catfish (Lophiosilurus alexandri) during transport procedure (400 $\mu \mathrm{g} \mathrm{L}-1)$. Because it can not increased fish metabolism and decreased stress parameters. Dinesh et al., (2017) provided tabacco leafs (Nicotiana tabacum) to rohu fingerling fish (Labeo rohita) as sedative chemical in order to transport. They expressed that this leaf dust of tabacco can be used to successive transport fish. Since, it prevented to increased stress parameters and metabolic activity.

\section{The Third Trial of the Transport in the $60 \mathrm{mg} \mathrm{L-1} \mathrm{of}$} Tricaine Solution

Glucose was 40-55 mg dL-1 in the C, AT and TP, while it decreased $25-30 \mathrm{mg} \mathrm{dL}-1$ in the recovery (Figure 5). Cortisol was $35-40 \mathrm{ng} \mathrm{dL}-1$ in the $\mathrm{C}$ and $\mathrm{AT}$, while it decreased $25 \mathrm{ng}$ dL-1 in the TP and recovery (Figure 6). Sodium was 126-128 meq L-1 in the C, AT and recovery, while it decreased about 119-122 meq L-1 in the TP. Chloride was 110 meq L-1 in the C, AT and recovery, while it decreased 104-106 meq L-1 in the TP. Hematocrit and RBC did not change significantly (Table 3 ).

The third trial had the best results. Anaesthetic usage in transport positively affected and reduced stress parameters of Asian catfish. Glucose and cortisol were stable in TP. They did not change. $\mathrm{Na}^{\wedge}$ and $\mathrm{Cl}$ - were almost in balance. There are many studies showed the same results close to this study such as silver catfish (Rhamdia quelen) (Carneiro et al., 2009; Becker et al., 2012), rohu (Labeo rohita), silver carp (Hypophthalmichthys molitrix) (Hasan \& Bart, 2007; Dinesh et al., 2017), tropical ornamental fish (Puntius filamentosus) (Pramod et al., (2010), largemouth bass (Coreius guichenoti) (Zhao et al., 2014).

Hasan and Bart (2007) investigated quinaldine and benzocaine for transport of rohu (Labeo rohita) and silver carp (Hypophthalmichthys molitrix). They dedicated that both anaesthetics can be safe to use for protect health and survival rate of fish. Zalh et al. (2010) studied benzocaine, tricaine, metomidate and isoeugenol to anesthesia Salmo salar, Hippoglossus hippoglossus and Gadus morhus. Stress response, cortisol release increased to maximum level after $30 \mathrm{~min}$, but decreased to normal level after 3-4 h. Four anaesthetics can be used to fish for transport. 


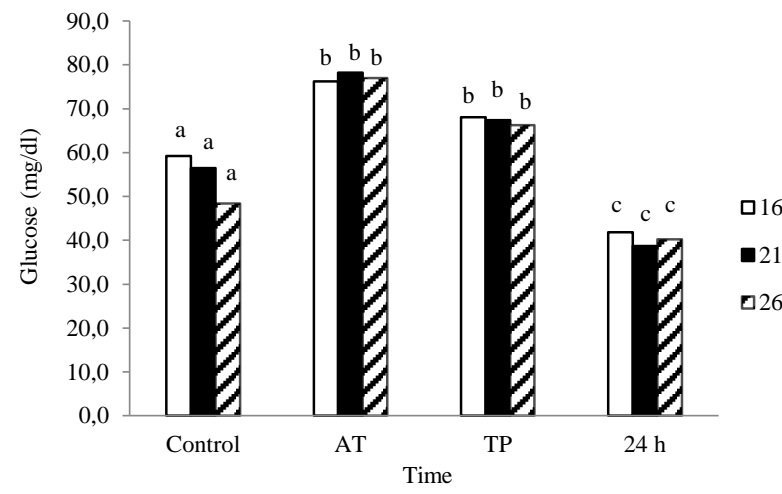

Figure 1. Glucose change of Asian catfish in the trial of transpo rt without tricaine

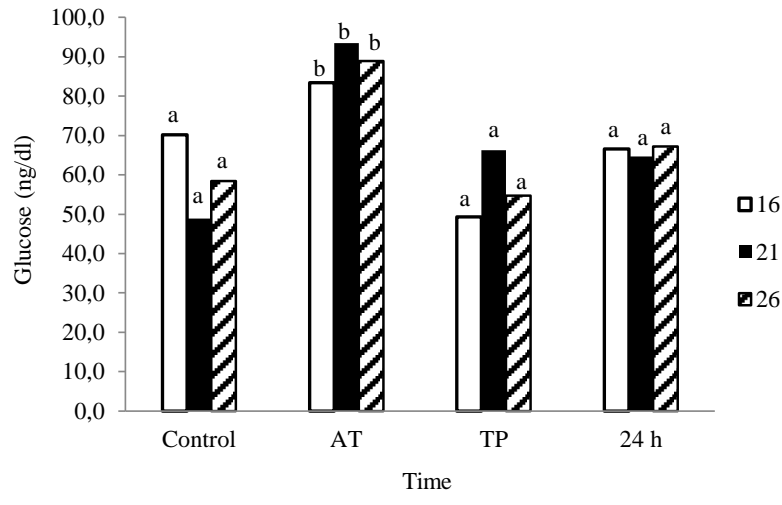

Figure 3. Glucose change of Asian catfish in the trial of transport with $40 \mathrm{mg} \mathrm{L}-1$ of tricaine

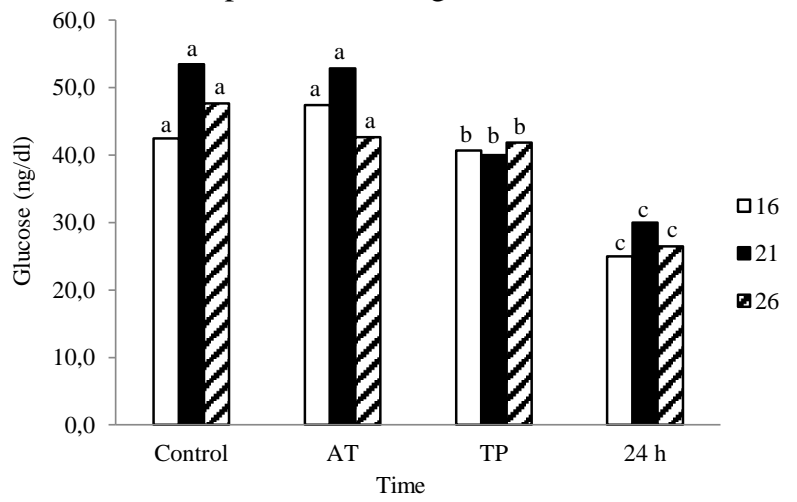

Figure 5. Glucose change of Asian catfish in the trial of transport with $60 \mathrm{mg} \mathrm{L}-1$ of tricaine

Pramod et al. (2010) compared tricaine and benzocaine to transport of $P$. filamentosus. They said both anaesthetics can mitigated stress parameters and improved survival after transport. Becker et al. (2012) suggest that eugenol and Lippia alba can be used to transport of silver catfish (Rhamdia quelen) in order to save fish health by decreasing stress.

Zhao et al. (2014) indicated that tricaine can be preferred if low temperature condition is needed during transport for largemounth bass (Coreius guichenoti). Berlinsky et al. (2016) studies four anaesthetics (tricaine, metomidate, clove oil and phenoxyethanol) for handling procedures in aquaculture Alosa pseudoharengus species as an anaesthetics for a longer sedation. They referred to only metomidate exposure did not increase cortisol. Balamurugan et al. (2016) said that clove oil can be positively used for transport of clownfish (Amphiprion

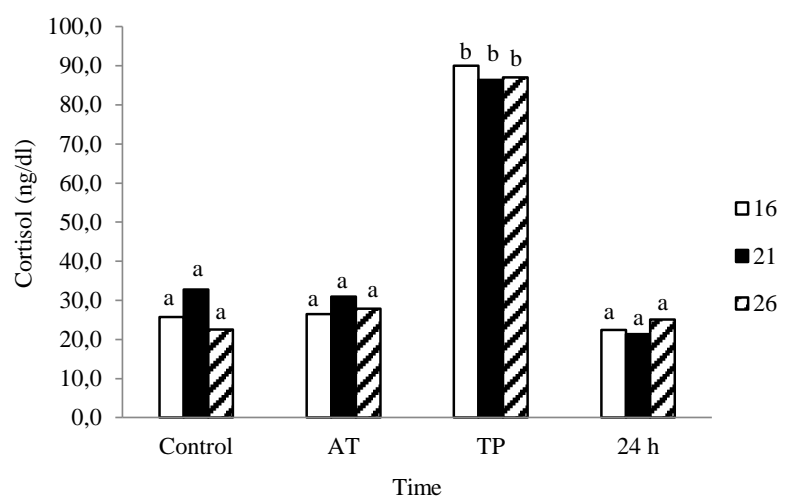

Figure 2. Cortisol change of Asian catfish in the trial of transport without tricaine

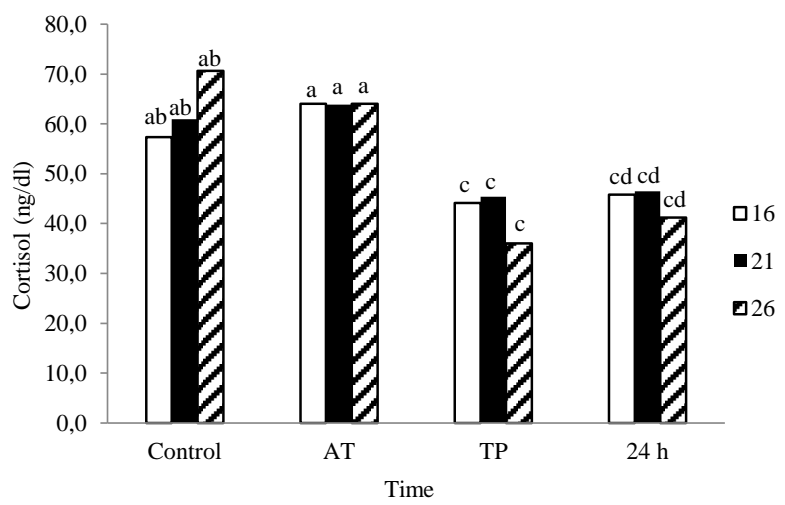

Figure 4. Cortisol change of Asian catfish in the trial of transport with $40 \mathrm{mg} \mathrm{L}-1$ of tricaine

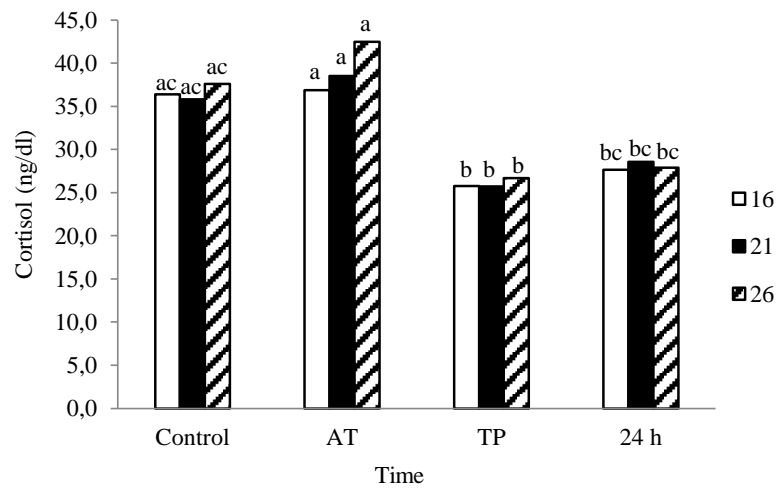

Figure 6. Cortisol change of Asian catfish in the trial of transport with $60 \mathrm{mg} \mathrm{L}-1$ of tricaine

sebae). Gil et al. (2016) reported that clove oil could have a possibility of use in transport of olive founder (Paralichthys olivaceus). However, Some researches reported anaesthetics did not enough decreased stress parameters. Sink and Neal (2009) supported that anaesthetic usage was not succeeded in the hybrid striped bass (Morone chrysops $\times$ M. saxatilis). Tondolo et al. (2013) dedicated that the anaesthetics used for fish transport did not reduce agitation and stress in fat snook (Centropomus parallelus). Mazandarani et al. (2017) exposed carp (C. carpio) to stress with (50, 100, $200 \mathrm{mg} \mathrm{L-1)}$ linalol. They reported that linalol did not aleviate the stress of transport.

\section{Histological Changes}

Histological alternations in the gills, spleen of Asian catfish were given in the Table 4 . Some effects were seen 
in the TP of transport without tricaine. They were hyperplasia and telanjiektasia in gills; increase of hemosterin clustering in spleen. Less effect was found in gills and spleen of fish exposed to $40-60 \mathrm{mg} \mathrm{L}-1$ of tricaine. Liver, kidney did not show any symptoms in these three trials. Transport with usage of $40-60 \mathrm{mg} \mathrm{L}-1$ of tricaine caused some positive effects on fish after transport. But it did not avoid to occur some histological symptoms. Hyperplasia, telajiektasia and edema were seen in gills. Manuel et al. (2014) also found some disorders in gills after transport of African catfish (Clarias gariepinus) such as tickness of lamella, changes of position of chloride cells.

Tablo 4. Significant histological evaluation of Asian catfish in the three trial of transport

\begin{tabular}{|c|c|c|c|c|}
\hline Trials & Stages & Histopathology & Tissue & Results \\
\hline \multirow{13}{*}{1} & \multirow{3}{*}{$\mathrm{C}$} & Hyperplasia & Gills & + \\
\hline & & Telanjiektasia & & + \\
\hline & & Hemosterin clustering & Spleen & + \\
\hline & \multirow{3}{*}{ AT } & Hyperplasia & & + \\
\hline & & Telanjiektasia & & + \\
\hline & & Hemosterin clustering & & + \\
\hline & \multirow{4}{*}{$\mathrm{TP}$} & Hyperplasia & Gills & ++ \\
\hline & & Telanjiektasia & & ++++ \\
\hline & & Edema & & ++ \\
\hline & & Hemosterin clustering & Spleen & ++ \\
\hline & \multirow{3}{*}{$24 \mathrm{~h}$} & Hyperplasia & Gills & + \\
\hline & & Telanjiektasia & & ++ \\
\hline & & Hemosterin clustering & Spleen & + \\
\hline \multirow{12}{*}{2} & \multirow{3}{*}{$\mathrm{C}$} & Hyperplasia & Gills & + \\
\hline & & Telanjiektasia & & + \\
\hline & & Hemosterin clustering & Spleen & + \\
\hline & \multirow{3}{*}{ AT } & Hyperplasia & Gills & + \\
\hline & & Telanjiektasia & & + \\
\hline & & Hemosterin clustering & Spleen & + \\
\hline & \multirow{3}{*}{$\mathrm{TP}$} & Hyperplasia & Gills & + \\
\hline & & Telanjiektasia & & ++ \\
\hline & & Hemosterin clustering & Spleen & ++ \\
\hline & \multirow{3}{*}{$24 \mathrm{~h}$} & Hyperplasia & Gills & + \\
\hline & & Telanjiektasia & & ++ \\
\hline & & Hemosterin clustering & Spleen & ++ \\
\hline \multirow{12}{*}{3} & \multirow{3}{*}{$\mathrm{C}$} & Hyperplasia & Gills & + \\
\hline & & Telanjiektasia & & + \\
\hline & & Hemosterin clustering & Spleen & + \\
\hline & \multirow{3}{*}{ AT } & Hyperplasia & Gills & + \\
\hline & & Telanjiektasia & & + \\
\hline & & Hemosterin clustering & Spleen & + \\
\hline & \multirow{3}{*}{$\mathrm{TP}$} & Hyperplasia & Gills & + \\
\hline & & Telanjiektasia & & ++ \\
\hline & & Hemosterin clustering & Spleen & ++++ \\
\hline & \multirow{3}{*}{$24 \mathrm{~h}$} & Hyperplasia & Gills & + \\
\hline & & Telanjiektasia & & ++ \\
\hline & & Hemosterin clustering & Spleen & ++ \\
\hline
\end{tabular}

${ }^{*}$ C: Control, AT: After transfer, TP: Transport, 24 h: 24 hours after transport, 1: transport without tricaine, 2: transport with 40 mg/L of tricaine, 3: transport with $60 \mathrm{mg} / \mathrm{L}$ of tricaine

\section{Conclusions}

The first trial of transport without tricaine did not decreased stress parameters in transport Glucose and cortisol increased and ion balance was break down. The second trial of transport with $40 \mathrm{mg} \mathrm{L}-1$ of tricaine demonstrated that glucose and cortisol were in normal level. $\mathrm{Na}+$ and $\mathrm{Cl}$ - were in close to balance. The third trial of transport with $60 \mathrm{mg} \mathrm{L}-1$ of the tricaine provided with the stress parameters to fall. revealed that glucose and cortisol were low. And electrolyte balance of $\mathrm{Na}+$ and $\mathrm{Cl}$ were fine. Namely, tricaine had potential to use an anesthetics for transport of Asian catfish in aquaculture.

\section{Acknowledgements}

Thanks to Adnan Menderes University for supporting this research as Scientific Research Project (ZRF-17006). This research was presented in the 20th National Aquaculture Symposium, September 24-26, 2020, Mersin, Turkey.

\section{References}

Akar AMA. 2011. Effects of clove oil on the blue tilapia (Oreochromis aureus) by transportation stress. Journal of the Arabian Aquaculture Society, 6(1): 77-86. 
Acerete L, Balasch JC, Espinosa E, Josa A, Tort L. 2004. Physiological responses in Eurasian perch (Perca fluviatilis, L.) subjected to stress by transport and handling. Aquaculture 237: 167-178.

Balamurugan J, Kumar TT, Prakash S, Meenakumari B, Balasundaram C, Harikrishnan R. 2016. Clove extract: A potential source for stress free transport of fish. Aquaculture, 454: 171-175.

Becker AG, Parodi TV, Heldwein CG, Zeppenfeld CC, Heinzmann BM, Baldisserotto B. 2012. Transportation of silver catfish, Rhamdia quelen, in water with eugenol and the essential oil of Lippia alba. Fish Physiology and Biochemistry, 38: 789-796

Becker AG, Luz RK, Mattioli CC, Nakayama C, Silva WDE, Leme FDP, Pinto Mendonça Mendes, HC, Heinzmann BM, Baldisserotto B. 2017. Can the essential oil of Aloysia triphylla have anesthetic effect and improve the physiological parameters of the carnivorous freshwater catfish Lophiosilurus alexandri after transport? Aquaculture, 481: 184-190.

Berlinsky, DL, Watson MT, DiMaggio MA, Breton TS. 20016. The Use of Tricaine Methanesulfonate, Clove Oil, Metomidate, and 2-Phenoxyethanol for Anesthesia Induction in Alewives. North American Journal of Aquaculture, 78:84-91.

Broom DM. 2005. The effects of land transport on animal welfare. Revue Scientifique et Technique Oie, 24: 683-691.

Carmichael, G.J., 1984. Long distance truck transport of intensively reared largemouth bass. The Progressive FishCulturist, 46: 111-115.

Carneiro PCF, Kaiseler PHS, Swarofsky EAC, Baldisserotto B. 2009. Transport of jundia' Rhamdia quelen juveniles at different loading densities: water quality and blood parameters. Neotropical Ichthyology, 7: 283-288.

Culling AF, Allison TR, Barr TW. 1985. Cellulary Patholog Technique. 4rt Ed. Mid-County Press, London, UK. pp. 23-46.

Dinesh R, Prakash C, Chadha NK, Poojary N, Abraham S. 2017. Does Tobacco (Nicotiana tabacum) Leaf Dust Save the Life of Rohu (Labeo rohita) Fingerlings During Transport? Journal of Aquatic Research and Development, 8: 474.

Ferreira JT, Schoonbee HJ, Smith G. 1984. The use of benzocaine-hydrochloride as an aid in the transport of fish. Aquaculture, 42: 169-174.

Gil, HW, Ko, MG, Lee, TH, Park I, Kim DS. 2016. Anesthetic effect and physiological response in olive flounder (Paralichths olivaceus) to clove oil in a simulated transport experiment. Development and Reproduction, 20(3): 255-266.

Gomes LC. 2007. Physiological responses of pirarucu (Arapaima gigas) to acute handling stress. ACTA Amazonica, 37(4): 629-634.

Iversen M, Finstad B, Nilssen KJ. 1998. Recovery from loading and transport stress in Atlantic salmon (Salmo salar L.) smolts. Aquaculture, 168: 387-394.

Hasan M, Bart AN. 2007. Improved survival of rohu, Labeo rohita (Hamilton-Buchanan) and silver carp, Hypophthalmichthys molitrix (Valenciennes) fingerlings using low dose quinaldine and benzocaine during transport. Aquaculture Research, 38: 50-58.

Kubilay A, Uluköy G. 2002. The effects of acute stress on rainbow trout (Oncorhynchus mykiss). Turkish Journal of Zoology, 26: 249-254.

Jentoft S, Aastveit AH, Torjesen PA, Andersen Q. 2005. Effects of stress on growth, cortisol and glucose levels in non-domesticated Eurasian perch (Perca fluviatilis) and domesticated rainbow trout (Oncorhynchus mykiss). Comparative Biochemistry and Physiology Part A, 141: 353-358.
Mazandarani M, Hoseini SM, Ghomshani MD. 2017. Effects of linalool on physiological responses of Cyprinus carpio (Linnaeus, 1758) and water physico-chemical parameters during transportation. Aquaculture Research, 48: 5775-5781.

Manuel R, Boerrigter J, Roques J, Van der Heul J, Van den Bos R, Flik G, Van de Vis H. 2014. Stress in African catfish (Clarias gariepinus) following overland transportation. Fish Physiology Biochemistry, 40: 33-44.

Park IS, Park MO, Hur JW, Kim DS, Chang YJ, Kim YJ, Park JY, Johnson SC. 2009. Anesthetic effects of lidocainehydrochloride on water parameters in simulated transport experiment of juvenile winter flounder, Pleuronectes americanus. Aquaculture, 294: 76-79.

Pramod PK, Ramachandran A, Sajeevan TP, Thampy S, Pai SS. 2010. Comparative efficacy of MS-222 and benzocaine as anaesthetics under simulated transport conditions of a tropical ornamental fish Puntius filamentosus (Valenciennes). Aquaculture Research, 41: 309-314.

Pedron JS, Miron DS, Rodrigues RV, Okamoto MH, Tesser MB, Sampaio LA. 2016. Stress response in transport of juvenile cobia Rachycentron canadum using the anesthetic benzocaine. Latin American journal of Aquatic Research, 44(3): 638-642.

Roberts RJ. 2012. Fish Pathology. Fourth Edition. Chapter 12. Laboratory Methods, Wiley-Blackwell, New York, USA. pp. 443-444.

Ross LG, Ross B. 2008. Anaesthetic and sedative techniques for aquatic animals, Blackwell, Ames. pp. 13-16.

Sink TD, Neal JW. 2009. Stress response and posttransport survival of hybrid striped bass transported with or without clove oil. North American Journal of Aquaculture, 71: 267275.

Svobodova Z, Kalab P, Dusek L, Vykusova B, Kolarova J, Janoukova D. 1999. The effect of handling and transport on the concentration of glucose and cortisol in blood plasma of common carp. ACTA VET BRNO, 68: 265-274.

Urbinati EC, Abreu JS, Camargo ACS, Parra MAL. 2004. Loading and transport stress of juvenile matrinxa (Brycon cephalus, Characidae) at various densities. Aquaculture, 229: 389-400.

Teo LH, Chen TW, Lee BH. 1989. Packaging of the guppy, Poecilia recticulata, for air transport in a closed system. Aquaculture, 78: 321-332.

Tondolo JSM, Amaral LDP, Simoes LN, Garlet QI, Schindler B, Oliveira TM, Silva BFD, Gomes LDC, Baldisserotto B, Mallmann CA, Heinzmann BM. 2013. Anesthesia and transport of fat snook Centropomus parallelus with the essential oil of Nectandra megapotamica (Spreng.) Mez. Neotropical Ichthyology, 11: 667-674.

Warris PD. 1998. The welfare of slaughter pigs during transport. Animal Welfare, 7: 365-381.

Zahl IH, Kiessling A, Samuelsen OB, Olsen RE. 2010. Anesthesia induces stress in Atlantic salmon (Salmo salar), Atlantic cod (Gadus morhua) and Atlantic halibut (Hippoglossus hippoglossus). Fish Physiology Biochemistry, 36: 719-730.

Zhao J, Zhu Y, He Y, Chen J, Feng X, Li, X, Xiong B, Yang D. 2014. Effects of temperature reduction and MS-222 on water quality and blood biochemistry in simulated transport experiment of largemouth bronze gudgeon, Coreius guichenoti. Journal of the World Aquaculture Society, 45: 493-507. 